\title{
Screening for sexually transmitted infection pathogens in semen samples
}

\author{
RW Peeling $\mathrm{PhD}^{1}$, J Embree $\mathrm{MD}^{2}$
}

RW Peeling, J Embree. Screening for sexually transmitted infection pathogens in semen samples. Can J Infect Dis Med Microbiol 2005;16(2):73-76.

\begin{abstract}
The transmission of sexually transmitted infection (STI) pathogens from an infected donor to the recipient of a semen donation in assisted conception may result not only in acute infection but also in longterm reproductive complications or adverse outcomes of pregnancy, including infection of the offspring. Screening for bacterial STI pathogens, Chlamydia trachomatis and Neisseria gonorrhoeae is strongly recommended because these pathogens can cause serious reproductive complications in the recipients of semen donations and infection in their offspring. Screening for these pathogens should be performed using the most sensitive methods, such as nucleic acid amplified tests. False-negative results due to inhibitory substances in the semen sample should be monitored using amplification controls. Where specimen transport is not a problem and culture facilities are available, $N$ gonorrhoeae can also be detected by culture. Laboratories performing screening should subscribe to proficiency programs and have strict quality controls. Although Trichomonas vaginalis, group B streptococcus and genital mycoplasmas have been associated with adverse outcomes of pregnancy, the frequent finding of these organisms in healthy individuals brings into question the validity of mandatory inclusion of these organisms in the screening panel. Although viral STI pathogens and Treponema pallidum - the causative agent of syphilis - may be detected in semen, their presence may be more sensitively detected through antibody testing of the donor. Screening donors for HIV, hepatitis B and syphilis by serology is uniformly recommended in all of the guidelines, but the value of screening either donors or semen samples for cytomegalovirus, herpes simplex viruses and human papilloma viruses is less clear.
\end{abstract}

\author{
Dépistage des MTS dans les échantillons de \\ sperme
}

La transmission des MTS (maladies transmissibles sexuellement) entre un donneur infecté et la receveuse d'un don de sperme lors d'une fécondation artificielle peut entraîner non seulement une infection aiguë chez la mère et l'enfant, mais également des problèmes de fertilité à long terme. Le dépistage des bactéries Chlamydia trachomatis et Neisseria gonorrhoeae, en cause dans les MTS, est fortement recommandé parce que ces agents pathogènes peuvent provoquer de graves complications au niveau de l'appareil reproducteur des receveuses et infecter le bébé. Le dépistage de ces agents pathogènes doit être effectué à l'aide des méthodes les plus sensibles, comme les tests d'amplification de l'acide nucléique. Les résultats faussement négatifs dus à des substances inhibitrices dans l'échantillon de sperme doivent être vérifiés à l'aide de contrôles d'amplification. Lorsque le transport des spécimens ne pose pas de problème et que l'établissement dispose de laboratoires d'hématologie, il est également possible de déceler la présence de $N$ gonorrhoeae au moyen d'hémocultures. Le laboratoire responsable du dépistage doit souscrire à des programmes d'homologation et exercer un strict contrôle de la qualité. Bien que Trichomonas vaginalis, les streptocoques du groupe B et les mycoplasmes génitaux aient été associés à des effets négatifs sur la grossesse, la présence fréquente de ces agents chez des individus en bonne santé remet en question le bien-fondé de leur dépistage systématique. Bien que les agents viraux responsables des MTS et Treponema pallidum, l'agent causal de la syphilis, puissent être décelés dans le sperme, leur présence peut être détectée avec plus de précision par le dépistage des anticorps chez le donneur. Le dépistage du VIH, de l'hépatite B et de la syphilis par analyses sérologiques chez les donneurs est systématiquement recommandé dans toutes les directives, mais l'utilité du dépistage du cytomégalovirus, de l'herpès simplex et du papillome humain chez les donneurs et sur les échantillons de sperme est moins claire.

Key Words: Best practice; Semen screening; Sexually transmitted infections

The present guidelines are intended for laboratories 1 involved in the testing of semen samples to ensure, within the limitations of existing laboratory methods, that the donated semen samples are free from pathogens that can cause sexually transmitted infections (STIs).

Testing of semen specimens for STI pathogens is not recommended as a means of diagnosis of clinical syndromes in donors of assisted conception programs, nor should these specimens be used in tests of cure following treatment. Donors generally undergo vigorous screening for STIs before they are accepted into a semen donation program (1-6). Individuals who have been diagnosed with STIs or who have previously received STI treatment should not be considered suitable donors for anonymous assisted conception programs. However, on occasion, the testing of archived semen samples may be the only method of determining whether an infectious agent is present when more appropriate specimens are not available, or when there is a strong wish to use the sperm from the donor for attempted conception. Semen samples from a donor who has not been previously tested for hepatitis viruses $B$ and C, HIV or human T-lymphotropic virus $1 / 2$ should be discarded.

${ }^{1}$ World Health Organization, Geneva, Switzerland; ${ }^{2}$ Department of Medical Microbiology, University of Manitoba, Winnipeg, Manitoba Correspondence: Dr RW Peeling, Special Programme for Research and Training in Tropical Diseases, World Health Organization,

1211 Geneva 27, Switzerland. Telephone 41-22-791-3741, fax 41-22-791-4854, e-mail peelingr@who.int 
TABLE 1

Screening for sexually transmitted infections in semen specimens

\begin{tabular}{lll}
\hline Pathogen & $\begin{array}{c}\text { Recommended } \\
\text { detection in semen }\end{array}$ & Detection method \\
\hline Bacteria & NAAT \\
Chlamydia trachomatis & ++ & Culture/NAAT \\
Neisseria gonorrhoeae & ++ & Culture/PCR \\
Mycoplasmas & + & Culture \\
Group B streptococcus & + & (serology) \\
Treponema pallidum & - & \\
Protozoa & + & Culture/PCR \\
Trichomonas vaginalis & + & \\
Viruses & - & (serology) \\
HIV 1 and 2 & - & (test for surface antigen) \\
Hepatitis B virus & - & (serology) \\
Hepatitis C virus & + & (serology) \\
Cytomegalovirus & - & NA \\
Herpes simplex virus & - & NA \\
Human papillomavirus & &
\end{tabular}

Screening of donors using methods in brackets are recommended. + May be considered, but insufficient data for mandatory recommendation; ++ Strongly recommended; - Semen testing for these pathogens is not recommended. NA Not applicable; NAAT Nucleic acid-based amplification test; PCR Polymerase chain reaction

These guidelines, therefore, do not address issues related to what testing methods should be used for donor screening, which pathogens should be included in the donor screening panel, or the frequency of STI screening for individuals in semen donation programs. Those issues are addressed by guidelines for STI screening of donors developed by various relevant professional societies and disease control agencies (1-4).

\section{OBJECTIVES OF SCREENING SEMEN SAMPLES FOR STIS}

The objective of screening semen samples before they are used for assisted reproduction procedures is to protect the recipients of semen donations and their offspring from bacterial and viral STIs and their sequelae by preventing the transmission of STI pathogens from the donor to the recipient. The transmission of STI pathogens to the recipient of a semen donation may result not only in acute infection, but also in long-term reproductive complications in the recipient and possible adverse outcomes of pregnancy, including infection in the offspring (6-8).

\section{RATIONALE FOR INCLUSION OF STI PATHOGENS IN THE SCREENING PANEL}

Ideally, the decision on what should be included in the screening panel should be evidence-based (Table 1). In reality, little data exist to support such decisions $(2,6,7)$. Although viral STI pathogens and Treponema pallidum, the causative agent of syphilis, may be detected in semen, these infections are more sensitively detected through antibody testing of the donor. Screening donors for HIV, hepatitis B and syphilis by serology is uniformly recommended in all of the guidelines, but the value of screening either donors or semen samples for cytomegalovirus, herpes simplex viruses and human papilloma viruses is less clear $(7,9,10)$.

The bacterial STI pathogens Chlamydia trachomatis and Neisseria gonorrhoeae can cause serious reproductive complications such as pelvic inflammatory disease, ectopic pregnancy and tubal infertility in the recipient, and ophthalmia neonatorum and pneumonia in the neonate. Therefore, tests for $\mathrm{C}$ trachomatis and $\mathrm{N}$ gonorrhoeae must be included in the panel for STI screening of semen samples $(1,7,11)$. Although Trichomonas vaginalis, Group B streptococcus and the genital mycoplasmas, including Ureaplasma urealyticum, have been associated with adverse outcomes of pregnancy, the frequent finding of these organisms in healthy individuals brings into question the validity of mandatory inclusion of these organisms in the screening panel (12-14).

\section{GUIDING PRINCIPLES FOR TESTING LABORATORIES}

To ensure that donated semen samples intended for assisted conception are free of pathogens that cause bacterial and viral STIs in the recipient, laboratories must use the most sensitive and specific laboratory tests available for the detection of each STI pathogen in the screening panel. Because no laboratory test is $100 \%$ sensitive and specific, false-positive and falsenegative results are inevitable. For semen screening, falsenegative results may lead to more serious consequences. Therefore, every effort should be made to monitor and minimize false-negative results; in particular, those due to inhibition of nucleic acid-based amplification tests (NAATs). STI pathogens generally survive the freezing process; therefore, the screening of STI pathogens in both fresh and cryopreserved semen samples is essential.

\section{STI SCREENING OF SEMEN SAMPLES}

Recommended laboratory tests to be used for screening C trachomatis: $C$ trachomatis can be diagnosed in the laboratory by culture, antigen detection tests such as enzyme immunoassays, or nucleic acid-based tests with or without amplification (see Can J Infect Dis Med Microbiol 2005;16[1]:39-44). Culture was recognized as the reference or 'gold' standard test in the detection of $\mathrm{C}$ trachomatis until the advent of NAATs (15-19). Although considered to be $100 \%$ specific, culture is technically demanding, requires a cold chain to preserve specimen viability in transport, and is not widely available. The use of antigen detection or nucleic acid hybridization tests is not recommended due to their low sensitivity, especially in asymptomatic individuals. NAATs have replaced culture as the reference standard for the laboratory diagnosis of $\mathrm{C}$ trachomatis.

Several NAATs are commercially available in Canada, all of which are more sensitive than culture or enzyme immunoassay. These tests detect and amplify nucleic acid from $\mathrm{C}$ trachomatis based on technologies such as polymerase chain reaction (PCR), ligase chain reaction, strand displacement amplification and transcription-mediated amplification. These tests have been approved for urine specimens and urethral and cervical swabs but not for semen specimens. Laboratories must therefore validate their test sensitivity using chlamydiapositive control specimens before proceeding with screening. N gonorrhoeae: Culture remains the gold standard for the laboratory diagnosis of gonorrhea $(19,20)$ (also see Can J Infect Dis Med Microbiol 2005;16[1]:15-25). Antigen detection tests for the detection of $N$ gonorrhoeae are commercially available but their use is not recommended due to low test sensitivity. NAATs may offer increased sensitivity compared with culture 
for the detection of $N$ gonorrhoeae in settings where preserving pathogen viability during specimen transport is a problem. There have been reports of false-positive NAAT results due to cross-reaction with other Neisseria species $(21,22)$. A positive finding by NAAT should therefore be confirmed (see below for confirmatory testing).

NAATs for $N$ gonorrhoeae have been approved for urine specimens and urethral and cervical swabs but not for semen specimens. Laboratories must therefore validate their test sensitivity using positive control specimens before proceeding with screening.

Multiplex NAAT: At the time of writing, there are at least two commercial NAAT kits available in Canada for the simultaneous detection of $\mathrm{C}$ trachomatis and $\mathrm{N}$ gonorrhoeae in the same specimen. The comments for the dedicated tests apply equally to the multiplex tests.

\section{Volume of specimen for testing}

The optimal amount of semen that should be used for such testing is not known. A survey of the literature showed that $10 \mu \mathrm{L}$ to $100 \mu \mathrm{L}$ have been used with PCR testing (16-18). Some sperm banks use a swab dipped into the semen sample, but whether this sampling method is adequate to maximize the sensitivity of NAATs is unclear at this time.

\section{Specimen processing}

The viscosity and the abundance of human DNA in a semen specimen may interfere with the ability of the primers to access the target DNA in order to initiate the annealing step in the NAAT amplification cycle. Protease digestion or dilution in a PCR buffer may overcome this interference without sacrificing test sensitivity. There is no standardized method for specimen processing. If a swab is dipped into the semen sample, then the swab should be processed according to the NAAT kit manufacturer's directions.

\section{Monitoring false-positive and false-negative results}

False-positive results: False-positive results may occur because of contamination during laboratory processing. Contamination can be addressed by stringent quality control measures in the laboratory (see articles on C trachomatis [Can J Infect Dis Med Microbiol 2005;16(1):39-44] and N gonorrhoeae [Can J Infect Dis Med Microbiol 2005;16(1):15-25]).

False-negative results: False-negative results may occur when the specimen or reaction mix contains substances that are inhibitory to the amplification reaction. Semen specimens have been shown to contain substances inhibitory to NAATs, but the nature of the inhibition is not known. In addition, the viscosity of semen specimens and the abundance of DNA in the samples may also compromise the sensitivity of detection. To ensure that no STI pathogens are transmitted in the process of assisted conception through donated semen, the presence of an internal amplification control to monitor inhibition is an absolute requirement. The PCR and strand displacement tests have amplification controls which will flag false-negative results if the artificial target provided in the specimen mix is not amplified. The amplification control is run simultaneously with the $\mathrm{C}$ trachomatis and $\mathrm{N}$ gonorrhoeae assays. For assays that do not have an amplification control, it is important that known quantities of $\mathrm{C}$ trachomatis and/or $N$ gonorrhoeae or a common human housekeeping gene is spiked into a duplicate specimen to monitor for false negatives.

A variety of methods have been shown to be effective in the resolution of inhibition in specimens for NAAT testing (22-24), including:

- heating the NAAT-ready sample at $95^{\circ} \mathrm{C}$ for $10 \mathrm{~min}$;

- leaving the NAAT-ready sample at $4^{\circ} \mathrm{C}$ overnight;

- purification of the semen specimen using DNA purification kits or phenol chloroform extraction;

- heating the semen specimen with Chelex (Bio-Rad Laboratories, Ontario) at $95^{\circ} \mathrm{C}$ for $15 \mathrm{~min}$, followed by centrifugation at $13,000 \mathrm{~g}$ for $5 \mathrm{~min}$.

Dilution of the specimen has also been shown to be effective for resolving inhibition, but it is not recommended for semen testing because it may compromise the sensitivity of screening.

A negative NAAT result should only be reported if the internal control result is positive, indicating that the amplification reaction was not inhibited.

\section{Indeterminate results}

If a result is considered to be indeterminate - that is, borderline or in the grey zone between a positive and negative result - retesting using a fresh aliquot of the specimen is recommended. If the result is indeterminate again, that sample should not be used in assisted conception procedures.

\section{Confirmatory testing}

Positive results by one NAAT may be confirmed using another NAAT. Alternatively, the same NAAT targeting another gene may be used. Cultures for $N$ gonorrhoeae should be confirmed by the use of tests such as carbohydrate fermentation or fluorescent antibodies.

\section{LABORATORY PROFICIENCY AND QUALITY ASSURANCE}

All testing laboratories performing semen testing must be accredited. In addition, testing laboratories should subscribe to national or international proficiency programs for each screening method used.

In general, laboratories performing NAATs must also follow stringent guidelines for avoiding contamination, such as unidirectional workflow, and the use of dedicated pipettes and other equipment.

\section{REFERENCES}

1. British Andrology Society. British Andrology Society guidelines for the screening of semen donors for donor insemination (1999). Hum Reprod 1999;14:1823-6.

2. Liesnard CA. Screening of semen donors for infectious diseases. Hum Reprod 1998;13(Suppl 2):12-24.

3. The American Society for Reproductive Medicine. Guidelines for gamete and embryo donation. Fertil Steril 1998;70(Suppl 3):1S-13S.

4. Critser JK. Current status of semen banking in the USA. Hum Reprod 1998;13(Suppl 2):55-67

5. Craig JM, Barratt CL, Kinghorn GR. Semen donors and STD screening. Genitourin Med 1997;73:280-3.

6. Greenblatt RM, Handsfield HH, Sayers MH, Holmes KK. Screening therapeutic insemination donors for sexually transmitted diseases: Overview and recommendations. Fertil Steril 1986;46:351-64.

7. Mascola L, Guinan ME. Screening to reduce transmission of sexually transmitted diseases in semen used for artificial insemination. N Engl J Med 1986;314:1354-9. 
8. Paavonen J, Wolner-Hanssen P. Chlamydia trachomatis: A major threat to reproduction. Hum Reprod 1989;4:111-24.

9. Bresson JL, Clavequin MC, Mazeron MC, et al. Risk of cytomegalovirus transmission by cryopreserved semen: A study of 635 semen samples from 231 donors. Hum Reprod 2003;18:1881-6.

10. Nieminen P, Koskimies AI, Paavonen J. Human papillomavirus DNA is not transmitted by semen. Int J STD AIDS 1991;2:207-8.

11. Nagel TC, Tagatz GE, Campbell BF. Transmission of Chlamydia trachomatis by artificial insemination. Fertil Steril 1986;46:959-60.

12. Barwin BN. Transmission of Ureaplasma urealyticum by artificial insemination by donor. Fertil Steril 1984;41:326-7.

13. Levy R, Layani-Milon MP, Giscard D'Estaing S, et al. Screening for Chlamydia trachomatis and Ureaplasma urealyticum infection in semen from asymptomatic male partners of infertile couples prior to in vitro fertilization. Int J Androl 1999;22:113-8.

14. Hill AC, Tucker MJ, Whittingham DG, Craft I. Mycoplasmas and in vitro fertilization. Fertil Steril 1987;47:652-5.

15. Black CM. Current methods of laboratory diagnosis of Chlamydia trachomatis infections. Clin Microbiol Rev 1997;10:160-84.

16. Wolff $\mathrm{H}$, Neubert U, Volkenandt M, et al. Detection of Chlamydia trachomatis in semen by antibody-enzyme immunoassay compared with polymerase chain reaction, antigen-enzyme immunoassay, and urethral cell culture. Fertil Steril 1994;62:1250-4.

17. Pannekoek Y, Westenberg SM, de Vries J, et al. PCR assessment of Chlamydia trachomatis infection of semen specimens processed for artificial insemination. J Clin Microbiol 2000;38:3763-7.
18. van den Brule AJ, Hemrika DJ, Walboomers JM, et al. Detection of Chlamydia trachomatis in semen of artificial insemination donors by the polymerase chain reaction. Fertil Steril 1993;59:1098-104.

19. Van Dyck E, Ieven M, Pattyn S, Van Damme L, Laga M. Detection of Chlamydia trachomatis and Neisseria gonorrhoeae by enzyme immunoassay, culture, and three nucleic acid amplification tests. J Clin Microbiol 2001;39:1751-6.

20. Martin DH, Cammarata C, Van Der Pol B, et al. Multicenter evaluation of AMPLICOR and automated COBAS AMPLICOR CT/NG tests for Neisseria gonorrhoeae. J Clin Microbiol 2000;38:3544-9.

21. Palmer HM, Mallinson H, Wood RL, Herring AJ. Evaluation of the specificities of five DNA amplification methods for the detection of Neisseria gonorrhoeae. J Clin Microbiol 2003;41:835-7.

22. Verkooyen RP, Luijendijk A, Huisman WM, et al. Detection of PCR inhibitors in cervical specimens by using the AMPLICOR Chlamydia trachomatis assay. J Clin Microbiol 1996;34:3072-4.

23. Mygind T, Birkelund S, Birkebaek NH, Ostergaard L, Jensen JS, Christiansen G. Determination of PCR efficiency in chelex-100 purified clinical samples and comparison of real-time quantitative PCR and conventional PCR for detection of Chlamydia pneumoniae. BMC Microbiol 2002;2:17.

24. Toye B, Woods W, Bobrowska M, Ramotar K. Inhibition of PCR in genital and urine specimens submitted for Chlamydia trachomatis testing. J Clin Microbiol 1998;36:2356-8. 


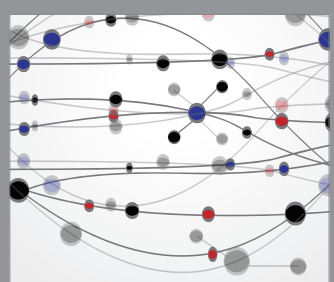

The Scientific World Journal
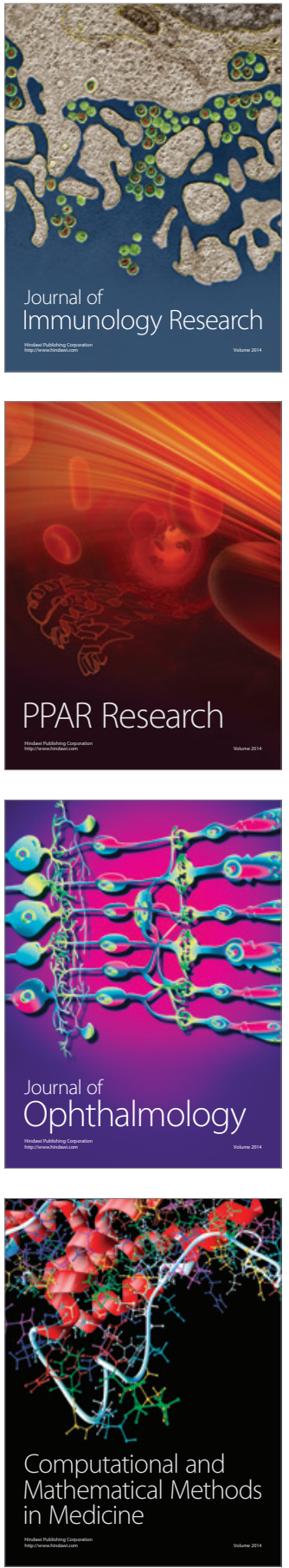

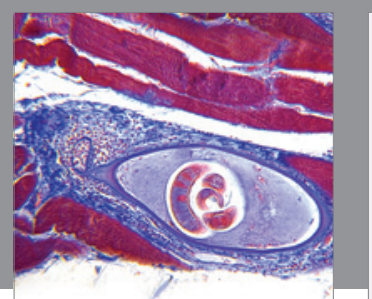

Gastroenterology Research and Practice

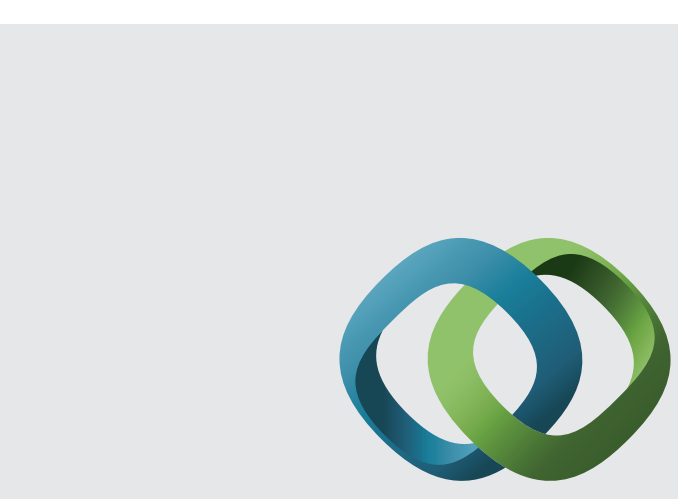

\section{Hindawi}

Submit your manuscripts at

http://www.hindawi.com

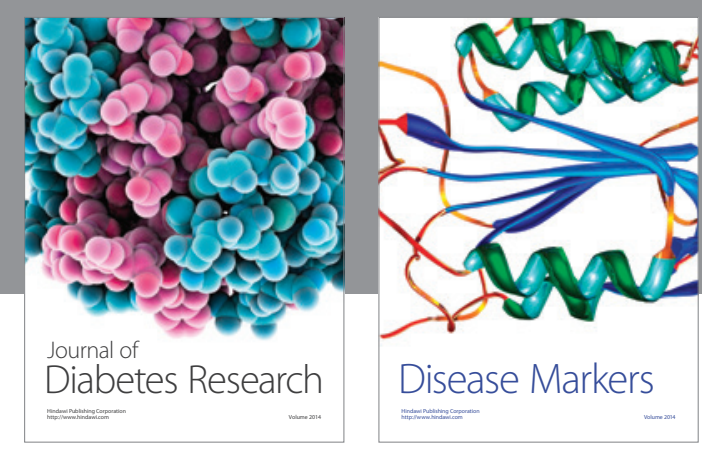

Disease Markers
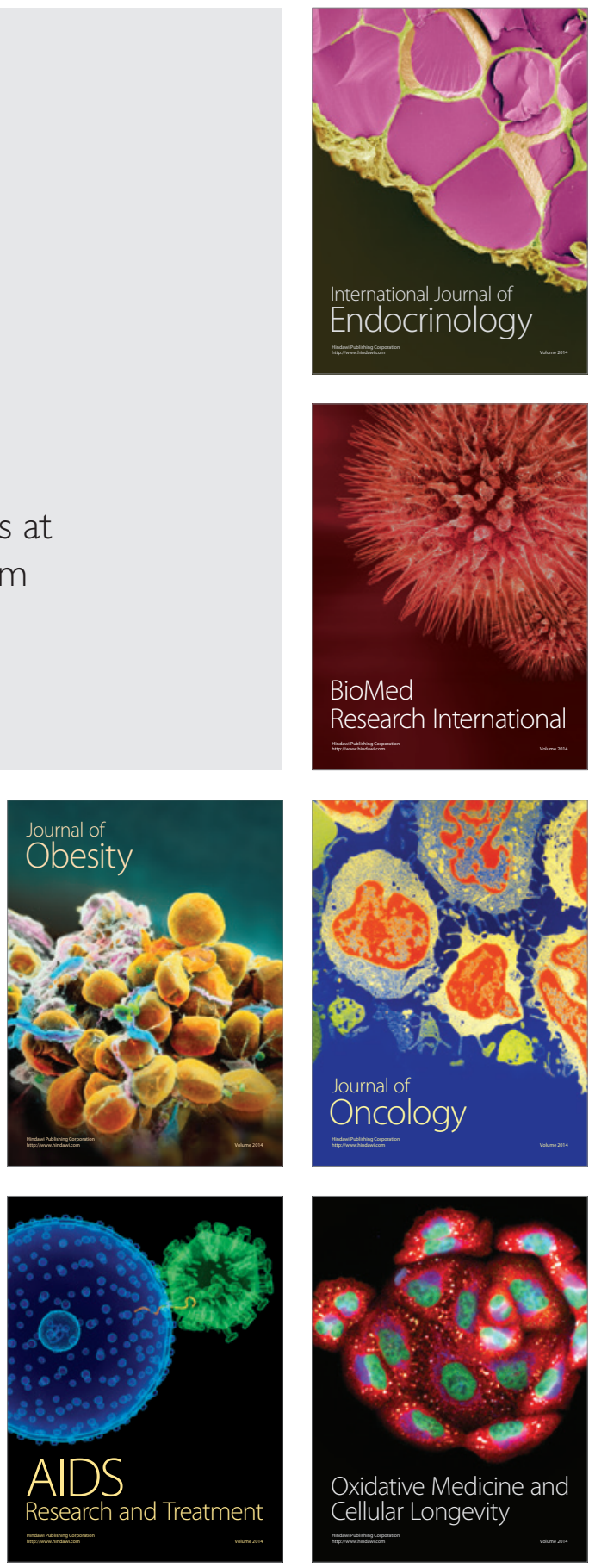